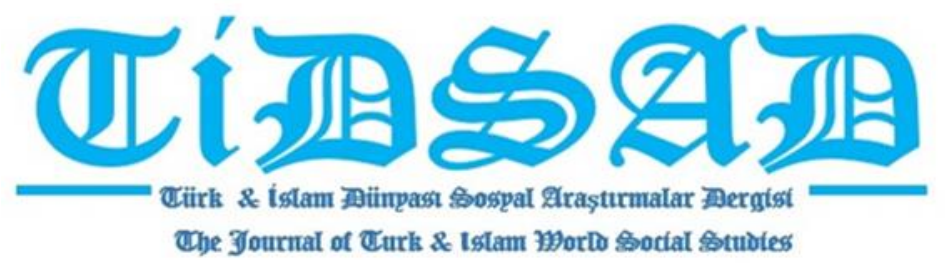

Yıl: 8, Sayı: 30, Eylül 2021, s. 82-100

\title{
Zeyneb TAHIRLI
}

Kocaeli Üniversitesi, zeynebtahirli93@gmail.com

Doç. Dr. Deniz DEMIRARSLAN

Kocaeli Üniversitesi Mimarlık ve Tasarım Fakültesi, demirarslandeniz@ gmail.com

\section{AZERBAYCAN TARIHINDE ÖNEMLİ YERİ OLAN İSMAILIYYE SARAYI'NIN ESKİ VE GÜNCEL DURUMUNUN İNCELENMESI}

\section{Özet}

Çalışmada Azerbaycan'ın başkenti Bakü'de bulunan ve şehrin önemli yapılardan biri olan İsmailiye Sarayı'nın eski hali ve restorasyon sonrası durumu incelenmiştir. 1908-1913 yılları arasında Azerbaycan'ın zenginlerinden Ağa Musa Nağıyev tarafından yapılmış olan bu saray çeşitli zamanlarda tarihi olaylara şahitlik etmiştir. 1918 Mart olayları sırasında hasar gören bina neredeyse tamamen yok edilmiştir. Birkaç sene sonra Sovyet Sosyalist Cumhuriyetler Birliği binayı yıkma kararı alsa da, yerel halkın itirazı nedeniyle binanın restorasyonuna başlanılmıştır. Binayı restore eden Sovyet iktidarı her zaman olduğu gibi yine bu sarayda da kendi izlerini bırakmaya çalışmıştır. Yapılan çalışmada nicel bilimsel araştırma yöntemlerinden nedensel-karşılaştırma yöntemi kullanılmıştır. Çalışmanın sonucunda İsmailiye Sarayı'nın geçirmiş olduğu restorasyon sürecinde özgün halini koruyamadığı görülmüştür.

Anahtar Kelimeler: Azerbaycan Mimarisi, Jozef Plosko, Ağa Musa Nağıyev, Kültür, İktidar

\section{INVESTIGATION OF THE OLD AND CURRENT STATUS OF THE ISMAILIYE PALACE, WHICH HAS AN IMPORTANT PLACE IN THE HISTORY OF AZERBAIJAN}

\footnotetext{
Abstract

The historical condition of the Ismailiye Palace, which is located in Baku, Azerbaijan's capital, and is one of the city's most prominent monuments, was compared to its current form following restoration in this research. This palace, which was built between 1908 and 1913 by Aga Musa Nagiyev, one of
} 
Azerbaijan's wealthiest men, had seen several historical occurrences. The building was nearly totally destroyed during the events of March 1918. Despite the fact that the Union of Soviet Socialist Republics intended to destroy the building a few years later, due to local opposition, the restoration of the structure began. The building was renovated by the Soviet administration. The Soviet administration, which rebuilt the structure, attempted, as it usually did, to stamp its imprint on it. The causal-comparison method, a quantitative scientific research method, was employed in the study. The analysis revealed that the Ismailiye Palace would not be able to maintain its original state during the restoration procedure.

Keywords: Azerbaijani Architecture, Jozef Plosko, Ağa Musa Nağıyev Culture, Political Power

\section{GíRİş}

Azerbaycan Cumhuriyet tarihinde önemli olaylara şahitlik etmiş İsmailiye Sarayı Bakü milyoneri Ağa Musa Nağıyev tarafından genç yaşta vefat eden oğlu İsmail'in anısına Müslüman Hayır Cemiyeti için inşa edilmiştir (Durmaz, 2010). Fahrettin Erdoğan, "Türk Ellerinde Hatıralarım" isimli kitabında cemiyetin faaliyetlerini şöyle anlatmaktadır: "İlk iş olarak Bakü Cemiyeti Hayriyesi'ne gittik, orada ileri gelenlerle tanıştık. Burada istiklal aşkıyla cemiyetler kurulmuş, durmadan çalışıyordu. O oturduğumuz İsmailiye binasında Musa Nağıyev'in 50 yataklı misafirhanesi vardı ki, her gelen Türk yolcusu burada aylarca kalır; yiyecek ve yatakla temin edildiği gibi, çamaşırları yıkanır; bütün masraf Nağıyev'in kasasından ödenir; misafirlerden bir tek kuruş bile alınmazdl. Bundan başka 200 yataklı bir de yetimhanesi vardı. Buraya cepheden toplanan kimsesiz çocuklar getirilerek bakımları sağlanmışt.." (Erdoğan, 1998). Bu ifadelerden Nağıyev'in binayı inşa ettirme amacı daha iyi anlaşılmaktadır. Polonyalı mimar Jozef Plosko tarafindan 1908-1913 yıllarında yapılan saray 23 Ocak 1945'den şimdiye kadar Azerbaycan Milli İlimler Akademisi Başkanlık Binası olarak faaliyet göstermektedir (Şekil-1). 


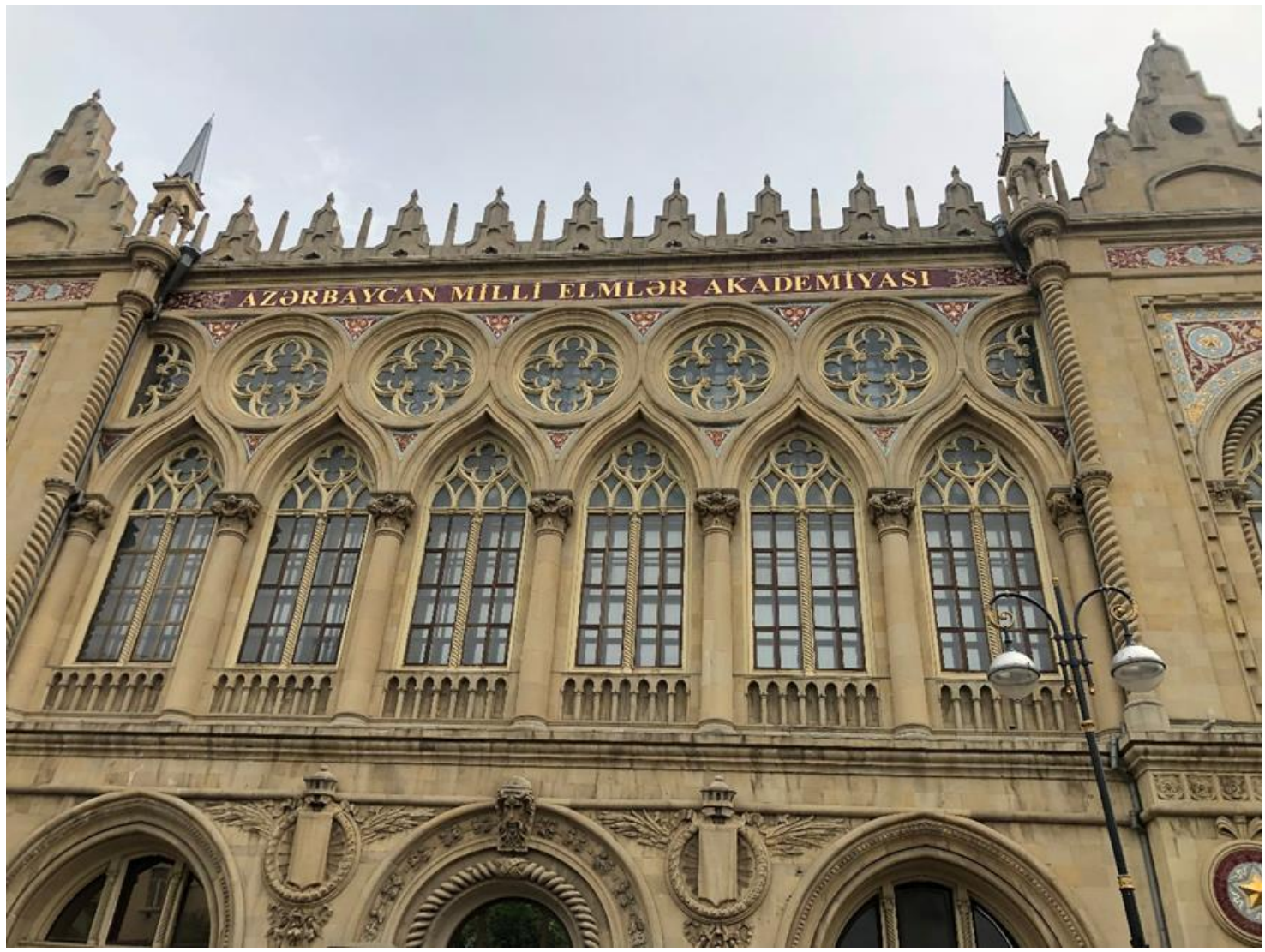

Şekil 1. Azerbaycan Milli İlimler Akademisi olarak kullanılan İsmailiye Sarayı (Zeynep Tahirli, 2021).

1918 Mart olayları sırasında Bakü'nün kontrolünü ele geçiren Ermeniler, sadece şehir nüfusuna değil, binalarına da zarar vermeye çalışmışlardır. $\mathrm{O}$ dönemde en çok hasar gören yapılardan biri İsmailiye Sarayı idi. 1918 Mart olayları esnasında sarayda çıkan yangında binaya verilen hasarın yanı sıra sarayın kendisi de dahil olmak üzere sarayda faaliyet gösteren kurumların arşivleri de yanarak yok olmuştur. Bakü'nün kurtuluşundan sonra Kafkas İslam Ordusu İsmailiye Sarayı'nın önünde onursal geçit töreni düzenlemiştir. Azerbaycan'da Sovyet iktidarı kurulduktan sonra sarayın yararsız halde olduğu gerekçesiyle yıkılmasına karar verilmiş; ancak yerel halkın itirazı nedeniyle 1923 yılında binanın restorasyonuna başlanılmıştır. Restorasyon sonrası bina bir müddet "Türk Kültür Sarayı" adını almış sonradan ise sırasıyla Azerbaycan Bilimsel Araştırma ve İnceleme Derneği, Azerbaycan Devlet Bilimsel Araştırma Enstitüsü, SSCB Bilimler Akademisi Transkafkasya Şubesi, SSCB Azerbaycan Ulusal Bilimler Akademisi ve Ocak 1945'den şimdiye kadar Azerbaycan Milli İlimler Akademisi Başkanlık binası olarak kullanılmıştır (URL-1, 2021).

Yapılan çalışmada Bakü'nün merkezinde yerleşen ve çeşitli zamanlarda tarihi olaylara şahitlik etmiş İsmailiye Sarayı'nın öncelikle tarihsel süreci tarihi kaynaklarla incelenmiştir. Çalışmanın sonraki aşamasında nicel bilimsel araştırma yöntemlerinden nedensel-karşılaştırmalı yöntem kullanılmıştır. Yapının sonuçta geçirmiş olduğu restorasyon sürecinin yapının orjinal mimari özelliklerini ne derece koruduğu yerinde gözlemlerle belgelenmiştir. 


\section{AZERBAYCAN MIMARISI}

Azerbaycan'ın mimarlık ve yerleşim tarihine bakıldığında eski zamanlara ait çok sayıda mağara olduğu görülmektedir. Büyük ve Küçük Kafkas Dağlarının eteklerinde, Talış Dağları, Nahçıvan Özerk Cumhuriyeti, Zengilan, Kelbecer, Gedebey, Göygöl, Şamahı ve son olarak da Füzuli bölgesinde bulunan Azıh mağarası önemli örneklerdir (Şekil-2). Bu tür mağaralarda yapılan araştırmalar göstermiştir ki, ilkel insanlar 1,5 milyon y1l önce mağaralardaki şartlara uygun yaşamak zorunda kalsalar da, daha sonra bilinçlerinin gelişmesi, bir takım emek ve inşaat araçlarının ortaya çıkması sonucunda yaşadıkları çevreyi kendi yaşam tarzlarına adapte etmeye çalışmışlardır (Aliyev, 2007).
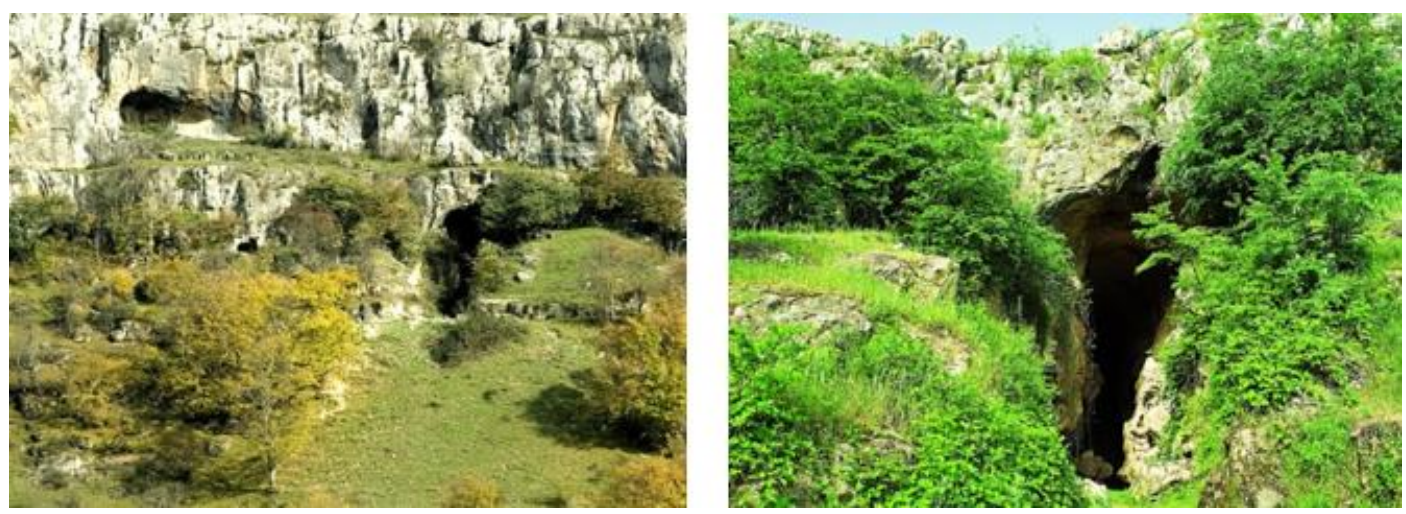

Şekil 2. Azıh mağarası, Hocavend, Alt Paleolitik Devri (URL-2, 2021).

Azerbaycan'da şehirlerin savunma yapıları ve görkemli kale duvarlarıyla birlikte ortaya çıkışı M.Ö. 9. Ve 7. Yüzyıllara rastlamaktadır. M.Ö. 4. yüzyı1 ve M.S. 7. yüzyılda şehircilik alanında önemli adımlar atılmış olan Azerbaycan'da İslam dininin yayılmasıyla birlikte mimarlıkta cami, medrese, türbe, kervansaray gibi yeni tarz binaların inşasına başlanılmıştır (URL-3). Giyasi'nin eserinde belirtmiş olduğu üzere Azerbaycan mimarisi, Orta Çağ'da İslam Dünyası'nın mimarisinin gelişmesinde önemli rol oynamıştır (Giyasi, 2015). 2003 yılında UNESCO tarafından Dünya Mirası olarak ilan edilen Demirkapı Derbent Kalesi bu dönemin önemli eserlerindendir (Şekil-3).

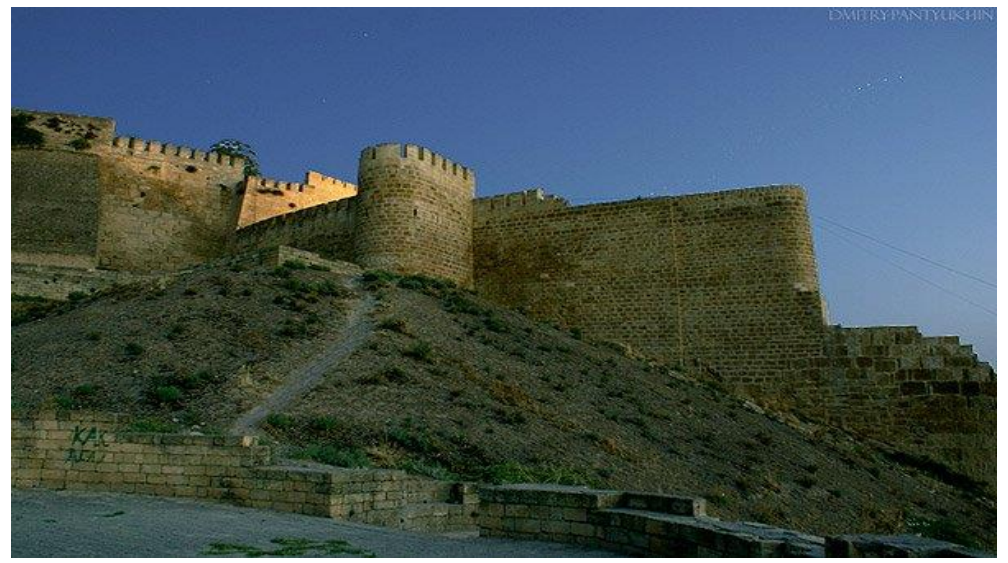

Şekil 3. "Demirkapı Derbent Kalesi”. Derbent şehrini savunma amacıyla, yapımı M.S. 5. ve 6. yüzyılda tamamlanmış antik kale duvarları, Dağıstan (URL-4, 2021). 
Farklı mimarlık üsluplarının ortaya çıktığı Azerbaycan'da 10. ve 12. yüzyıllardan günümüze depremler ve Moğol saldırıları nedeniyle yalnız içkale, kale duvarı, minare gibi yapılara ait çok sayıda harabe ulaşabilmiştir (URL-3). Bu yapılardan önemli bir örnek Şeki şehrinde bulunan Yukarı Kervansaray'dır (Şekil-4).

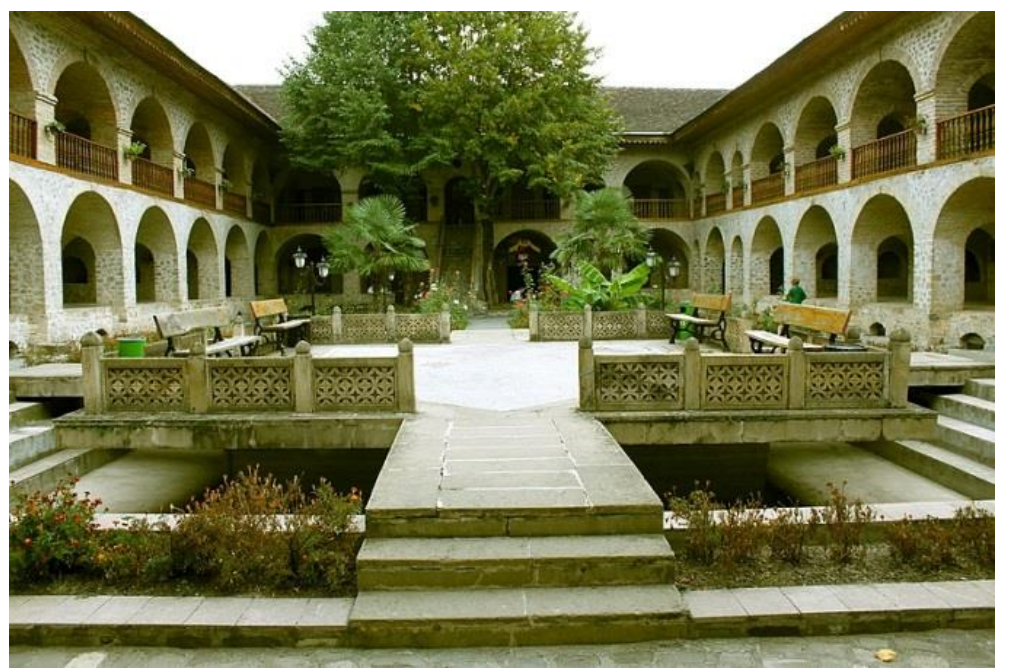

Şekil 4. Yukarı Kervansaray, yapımı 18. ve 19. yüzyılda tamamlanmış tuğla ve nehir taşından yapılmış kervansaray, Şeki, Azerbaycan (URL-5, 2021).

Rus egemenliği dönemindeki 19. Yüzyıldan itibaren Azerbaycan'da okul, hastane, tiyatro gibi yeni yapılar inşa edilmiştir (Şekil-5). Fabrikalar, atölyeler, liman, köprü gibi endüstri ve ulaşım tesislerinin yapımı da mimarideki yerini almıştır. Sovyet dönemi Azerbaycan konut mimarlığının ilk aşaması dönemin her sanayileşen kentinde olduğu gibi Bakü çevresinde de işçi kasabalarının kurulması ile başlamıştır. Yeni Bakü'nün bir sanayi şehri olarak doğuşu ilk endüstriyel petrol kuyusunun açılmasını takiben 1847 y1lına tarihlenebilmektedir. 1870'lerden Birinci Dünya Savaşı'na kadar olan dönem "ilk petrol patlaması" ya da "altın dönem" olarak adlandırılmıştır. Bu dönemden 1918 yılına kadar Bakü Barok tarzında muhteşem binaların yükselişine tanık olmuştur (Valiyev, 2013).

1940'ların sonunda dünyanın ilk petrol platformu olarak inşa edilen Petrol Taşları II. Dünya Savaşı sonrası mimarlık tarihi açısından önemlidir. Bağımsızlık kazandıktan sonra Bakü'de Haydar Aliyev Kültür Merkezi, Alev kuleleri gibi modern yapılar inşa edilmiştir (URL-3) (Şekil- 6).
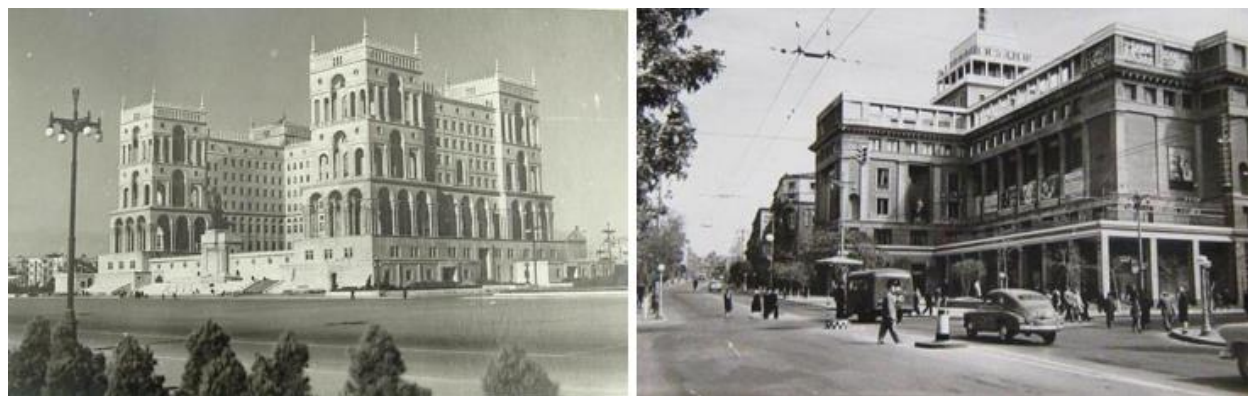

Şekil 5. Bakü Hükümet Binası (1936-1952) (URL-6, 2021) ve Nizami Sinema Salonu (1934), Bakü, Azerbaycan (URL-7, 2021). 

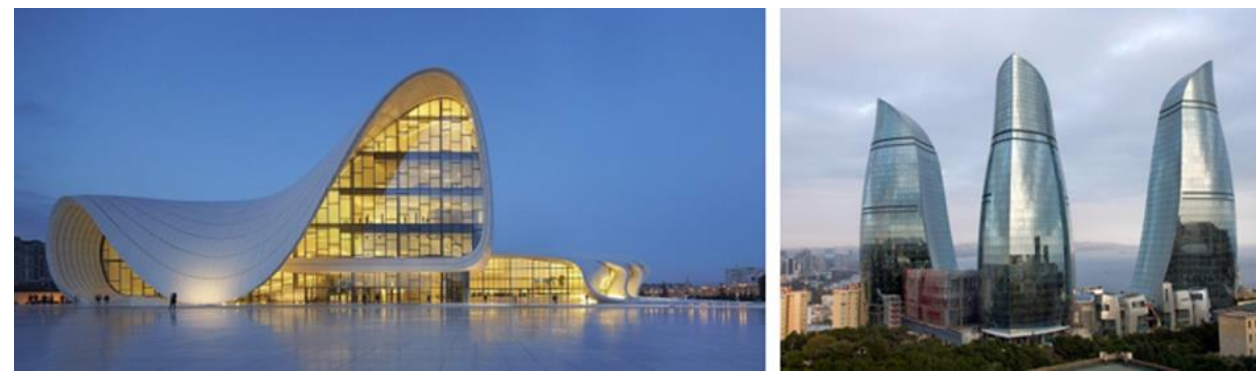

Şekil 6. Haydar Aliyev Kültür Merkezi (URL-8, 2021) ve Alev Kuleleri (URL-9, 2021).

\section{3.İSMAILIYY SARAYI}

15. Yüzyılda Şirvanşah Halillulah döneminde başkent olan Bakü şehri yüzyıllar boyunca (Boni, 2018), kale duvarları içinde gelişmiş ve sadece 19. yüzyılda şehir kale duvarlarının dışına doğru gelişmeye başlamıştır. Sipahi ise (2018) eserinde çok eski bir tarihe sahip olduğu düşünülen kentin ilk dönemlerine ilişkin kesin kayıtlar bulunmamakla birlikte bir liman kenti olarak 1. yüzyılda öne çıktığının görüldüğünü belirtmektedir. Dursun da eserinde (1991) ne zaman kurulduğu bilinmeyen şehrin adına ilk defa 10. yüzyıl İslâm coğrafyacılarının eserlerinde Bâkû, Bâkûh, Bâkuh ve Bâkûye şekillerinde rastlandığını belirtmektedir. 10.yüzyılda El Mesûdî, El Fârîsî, El İstahrî, İbn Havkal gibi Arap ve Fars bilim adamlarının kent hakkında yazıları mevcuttur. " Kitab al masalik val mamalik" in ("Yollar ve ülkeler hakkında kitap") yazarı El Fârîsî Azerbaycan'ın birçok şehrini ziyaret etmiş ve Bakü hakkında çok ilginç bilgiler vermiştir: "Bu ülkelerin denizine Taberistan Denizi denir. Klyısında Bab al-Abwab, Bakuh - Bakuhun şehirlerinde yağ ( petrol) var.” (Ferhadoğlu, 2006).

Türk-İslâm kültür merkezlerinden biri olan Bakü'de tarih boyunca çok sayıda cami, hamam, kervansaray ve kümbet gibi mimari eser inşa edilmiştir. Bugüne kadar gelenler içinde en eski ve önemlisi kale olup içinde bulunan eski Bakü'ye "İçerişehir" denilmektedir. İlk Bakü şehir planının tarihi 19. yüzyılın sonlarına kadar uzanmaktadır ve şehir içi kalenin (İçerişehir) planı yapılmıştır. Bu planda duvarların dışında yeni binaların inşası öngörülmüştür. Bu plan, Bakü'nün girişindeki Bayil bölgesinden kale surlarına kadar olan bölgeyi ayrıca, yoğun kirlilik ile karakterize edilen bir petrol çıkarma alanı olan Kara Şehir bölgesi ve Beyaz Şehir bölgesini kapsamaktaydı. Konut, ticaret ve finans alanlarının nasıl olması gerektiğinin tasarlandığı bu planı Albay N.A. Fonder Nonne, 18901898'de gerçekleştirmiştir (Valiyev, 2013). Ancak, 1883'te dış kale duvarının yıkılmasından sonra, binanın şimdi bulunduğu alan uzun bir süre gelişmeden kalmıştır. Bu yere "Gapan dibi" ("terazi yeri") deniyordu ve o günlerde pitoresk bir doğu pazarı olarak kullanılıyordu. Bu meydan şehrin en işlek yerlerinden biriydi. Şamahı, Ağdaş, Gökçay, Şeki, gibi diğer ilçeler ve çevre köylerden çeşitli mallar satışa getirilerek burada satışa sunuluyordu. "Şeytan Bazar" olarak 19. Yüzyılda isimlendirilen bu pazarın yerinde daha sonra yeni şehir planının da etkisiyle İsmailiye Sarayı yapılmıştır (Şekil-7) (URL-1, 2021). 


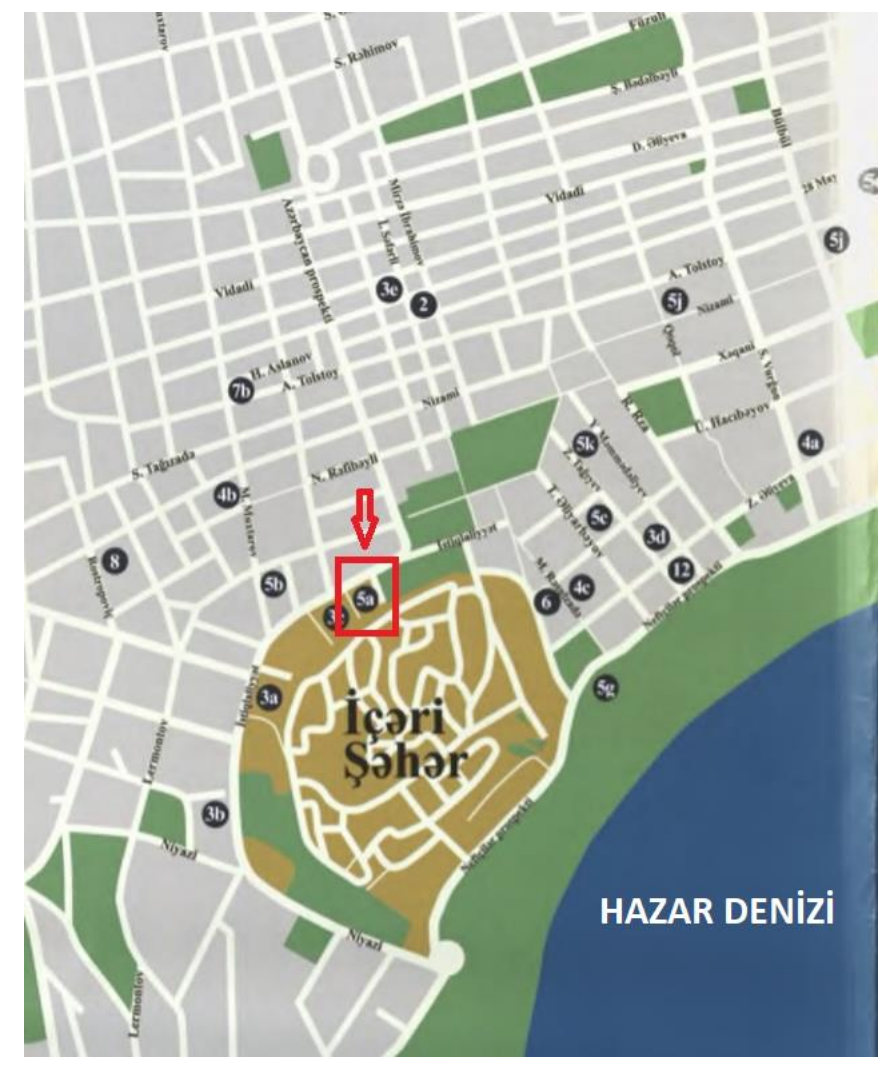

Şekil 7. Bakü şehir planı, İçerişehir planı ve İsmailiye Sarayı'nın yeri (Quretski, 2012).

Zamanının ünlü milyoneri olan Ağa Musa Nağıyev'in Bakü'de yaptırmış olduğu 98 binadan biri ve en önemlisi olan İsmailiye Sarayı'nın temeli 1907 yılında atılmıştır. Dönemin yaygın görülen hastalıklarından biri olan verem hastalığı nedeniyle genç yaşta ölen oğlu İsmail'in anısına bina yaptıran Ağa Musa Nağıyev bu binayı Muhtarov Sarayı, Polşa Katolik Kilisesi, Bakü Kukla Tiyatrosu, Yeni Avrupa Oteli gibi çok sayıda yapının mimari olan Polonyalı mimar Jozef Plosko'ya ${ }^{1}$ (1867- 1931) Müslüman Hayır Cemiyeti için yaptırmıştır. Yapımı 1913 yılında tamamlanmış ve mimari özelliklerinden dolayı şehrin en görkemli yapısı olarak bilinen İsmailiye Sarayı hakkında Azerbaycan Halk Cumhuriyeti kurucusu Mehemmed Emin Resulzade "Azerbaycan Cumhuriyeti" adlı kitabında şöyle demiştir: "Belki de böyle bir amaç için inşa edilen binaların ihtişamı açısından bu bina İslam dünyasında bir ilktir." (Resulzade, 1990) (Şekil-8). Mimar Rizvan Qarabağlı da saray hakkında şöyle belirtmektedir: "Plosko her ne kadar Gotik üslubunu ă̆ırlıklı olarak uygulasa da binanın cephesinde Bakü’nün çevresiyle uyumlu olacak şekilde düzenlemelere yer vermiştir. Cephede kullanılan yivler özellikle Apşeron ${ }^{2}$ mimarisine atıfta bulunmaktadır." Azerbaycan'ın son dönemdeki önemli mimarlarından merhum Fazil Memedov ise binayı eklektik ama büyük ölçüde Venedik Gotiği olarak tanımlamıştır (URL-13, 2012).

\footnotetext{
${ }^{1}$ Sadece Plosko değil; Y.Y.Skibinskiy (1858-1928), I.V.Koslavski (1865-1904), K.B.Skurevich (1866-1950) gibi Polonyalı mimarlar Bakü'de konut binaları, konaklar, saraylar, evler, kültürel ve sivil binalar inşa etmiştir.

${ }^{2}$ Azerbaycan'da stratejik öneme sahip bir yarımada.
} 
Bakü'de Gotik tarzda yapılmış ilk bina olan İsmailiye Sarayı'nın yerinde başlangıçta “Cuma Cami”sinin yapımı düşünülmekteyken, ancak bir sonraki caddede lüks bir Alexander Nevsky Katedrali yapılmakta olduğu için bu teklif Çarlık yetkilileri tarafindan reddedilmiş ve caminin yerinde İsmailiye Sarayı'nın yapımına izin verilmiştir (Şekil-9) (Fetullayev-Figarov, 2013).

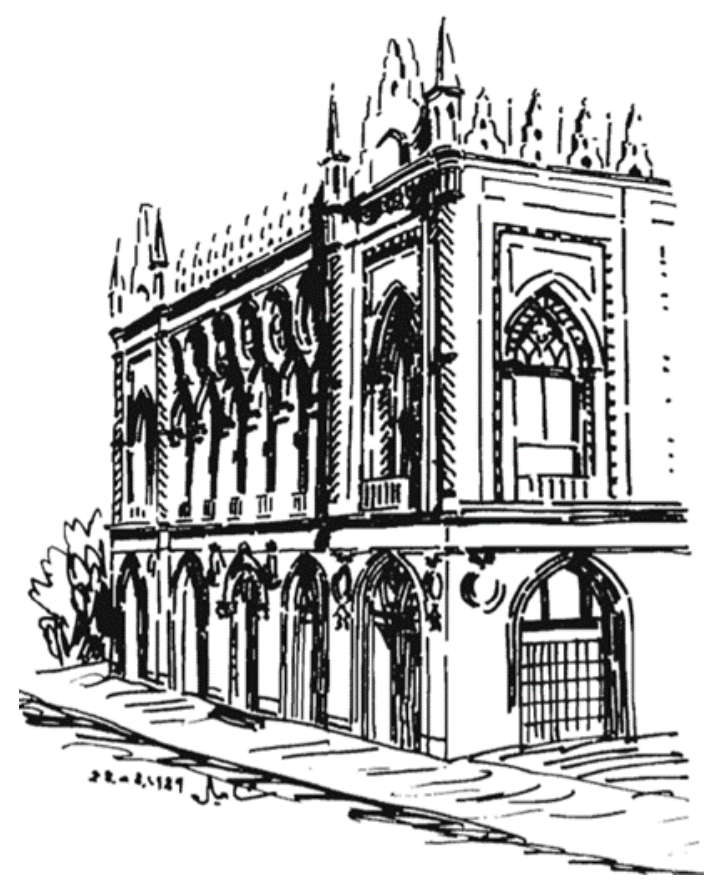

Şekil 8. Bir mimari eskizde İsmailiye Sarayı (Fetullayev-Figarov, 2013).

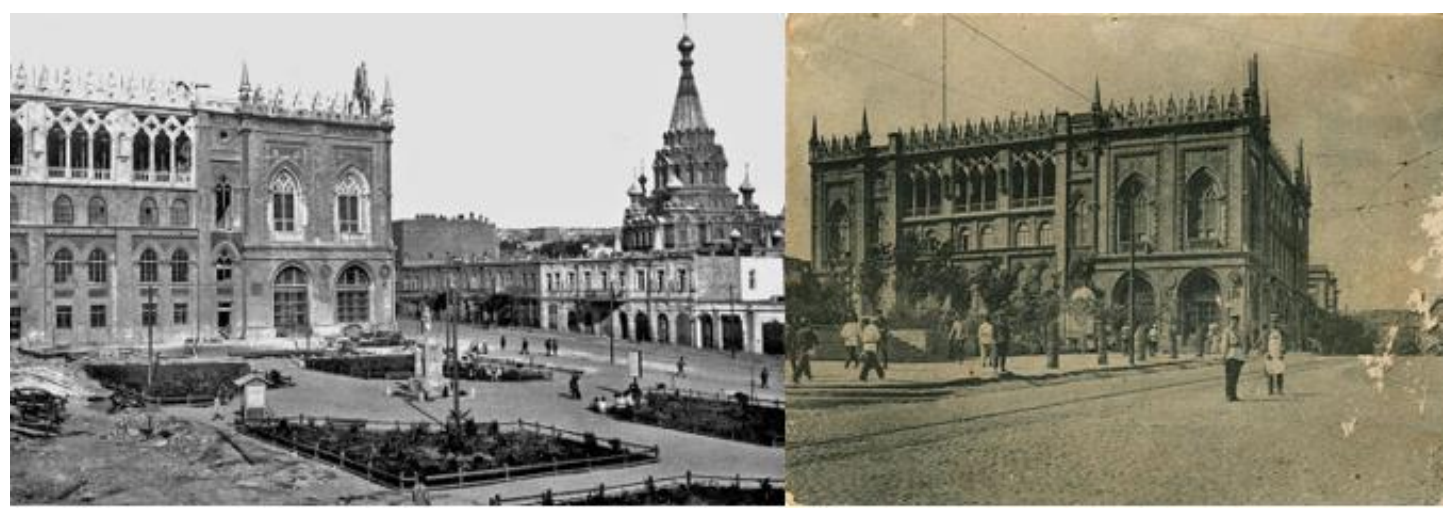

Şekil 9. Sol tarafta İsmailiye Sarayı ve karşısında Alexander Nevsky Katedrali ve geçmişten bir görünüm (URL-1, 2021).

İnşas1 1913 yılında tamamlanmış olan binaya ilk taşınan Müslüman Hayır Cemiyeti’nin yönetimi olmuştur. Ardından Bakü’de var olan bütün eğitim cemiyetleri binaya taşınmıştır. Ancak bir y1l sonra Birinci Dünya Savaşının başlaması nedeniyle bina hastane olarak kullanılmaya başlanmıştır (URL-1, 2021). 
Daha önce de belirtildiği üzere 1918 Mart olaylarında binaya zarar verilmiştir. İlk başta yağmalanan binanın aynı zamanda ön cephesinde bulunan yaklaşık 6 kilogram ağırlıkta olan İsmailiye yazısı Ermeniler tarafından çalınmış, binada bulunan bütün arşivler yakılmış ve yok olmuştur (URL-10, 2021).

1920 y1lında Azerbaycan'da Sovyet Sosyalist Cumhuriyetler Birliği'nin kurulmasından sonra İsmailiye Sarayı’nın yıkımına karar verilmiş, ancak yerel halkın binanın önüne toplanarak itiraz etmesi nedeniyle restore edilmesine başlanılmıştır.

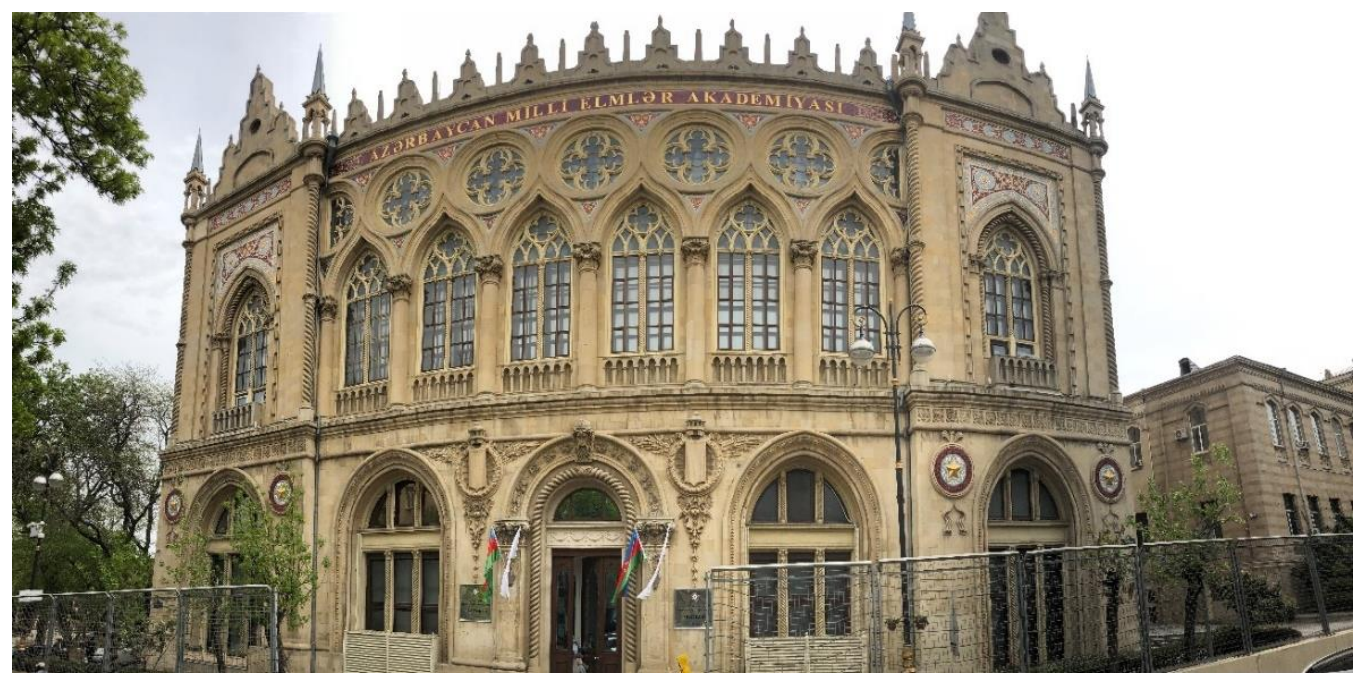

Şekil 10. İsmailiye Sarayı panoramik görünüm (Zeyneb Tahirli, 2021).

21 Ocak 1924 yılında SSCB'nin kurucusu Vladimir İliç Ulyanov'un (Lenin) vefatının ertesi sabahı 22 Ocak tarihinde "İsmailiye Sarayı"na Lenin'in adı verilmiş, ancak halk arasında bina "İsmailiye" olarak kalmış ve günümüze kadar da bilim ve eğitim alanında hizmet vermiştir. 1924 yılından sonra Azerbaycan Çalışma ve Araştırma Derneği, Türk Kültür Sarayı olarak faaliyete geçen bina SSCB Bilimler Akademisi Transkafkasya Şubesi'nin Azerbaycan Bölümü olarak kullanılmıştır. Bina 1945 yılından sonra Ulusal Bilimler Akademisi olarak değiştirilmiştir (Şekil-10). Şu an bina Azerbaycan Ulusal Bilimler Akademisi Başkanlık Binası olarak kullanılmaktadır. Bu binanın toplantı salonunda s1k sık bilimsel konferanslar, edebi tartışmalar yapılmıştır. Maksim Gorki, Vladimir Mayakovsky, Nazım Hikmet gibi yazarlar bu binanın toplantı salonunda okurlarıyla buluşmuş; Mehemmed Emin Resulzade ve Müsavat Partisi önemli konuşma ve toplantılarını bu binada yapmıştır (Yagublu, 2015) (Budak, 2018) (URL-1, 2021).

\subsection{Sarayın İç Mimari Özellikleri}

Polonya asıllı mimar Plosko'nun en önemli eserlerinden olan İsmailiye Sarayı'nın bulunduğu alan şehir planlamasında önemli rol oynayan Bakü'nün önemli caddelerindendir.

Bakü her dönem eşsiz mimarisiyle ünlü olmuştur ve şehirdeki en güzel yapılardan biri de Bakü mimarisinin incisi olarak kabul edilen İsmailiye Sarayı'dır. Bu binanın benzersizliği, farklı mimari stilleri birleştirmesidir. Avrupa Gotik geleneklerinde yapılan bina, oryantal desenlerle zengin bir şekilde süslenmiştir.

Sarayın iç mekânı, cephesinin aksine, Avrupa Klasiklerine daha yakın tarzda tasarlanmıştır. Bu ikinci katın zarif mimari çözümünde, salonun üç boyutlu halka açık fuayesini 
çevreleyen şekilli korint sütunlarında belirgindir (Şekil-11). Zarif, net çizgilere sahip sütunlar arasındaki dikdörtgen boşlukta mimari formların ve yöntemlerin asaleti açıkca hissedilmektedir. Burada keskin gotik biçimlerin dinamikleri, mimarinin tamamen farklı tezahürleriyle değiştirilmiş olup, mimari unsurların ve detayların oranlarının inceliği ve çizgilerinin sertliği bakımından Roma dönemi mimarisinin yansımaları görülmektedir. Plosko, sarayın iç mimarisinde sanatsal incelikler açısından Neoklasik üslupta önemli çalışmalar yapmıştır (Fetullayev-Figarov, 2013).

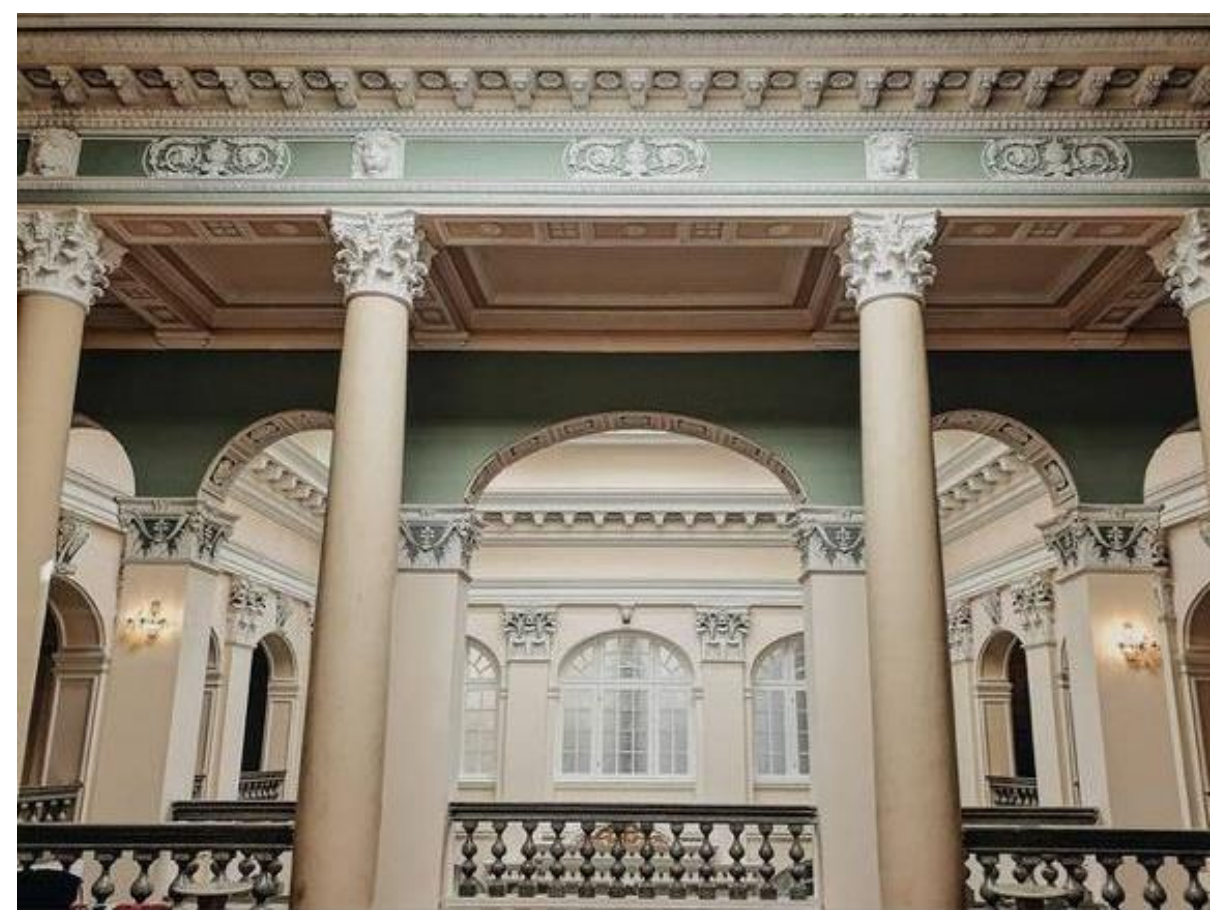

Şekil 11. İsmailiye Sarayı ikinci kat (Seyid, 2021).

Bina iyi düşünülmüş hacim çözümüne sahiptir. Sarayın ana girişi, mimari unsurların ve detayların muhteşem bir bileşimidir. Binanın zemin katında, uzun dikdörtgen bir antre ve sonrasında büyük iyonik sütunlu fuaye vardır. Giriş holünde zeminde siyah- beyaz diyagonal döşenmiş mermer döşeme kaplaması ve iyon başlıklı sütunlar arasında yükselen mermer trabzanlı antsal merdiven dikkati çekmektedir. Ardından geniş bir merkezi üç kollu merdiven ve fuayenin köşelerinde kapalı çift merdiven bulunmaktadır (Şekil-12,13). Giriş merdivenlerine paralel olarak servis odaları yapılmıştır (Fetullayev-Figarov, 2013). Kemerlerden oluşan birinci kat, formları anıtsal hale getirmektedir. Birinci katın pembe boyalı ve işlemeli tavanı, cam 1şıklıklı çatı iç mekâna zengin ve aydınlık bir görünüm kazandırmaktadır. İkinci kata girişte klasik tarzda yapılmış resimler eşlik etmektedir. 


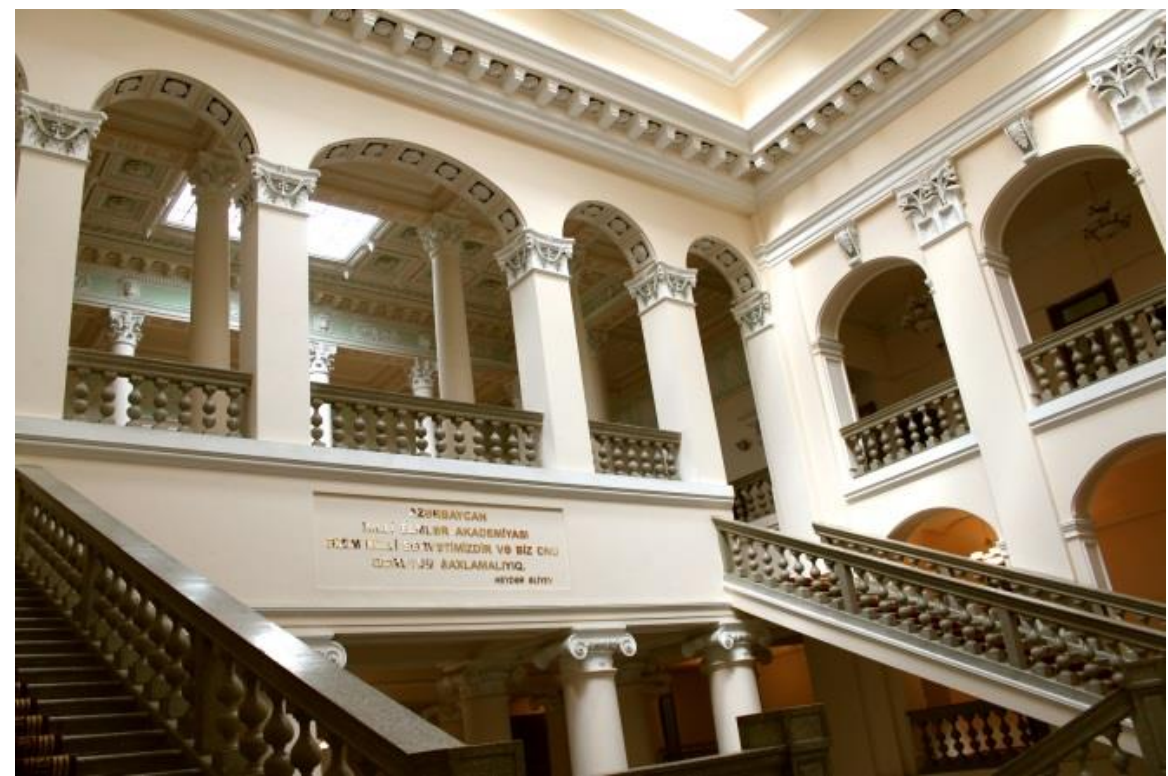

Şekil 12. İsmailiye Sarayı üç kollu merdiven (URL-1, 2021).

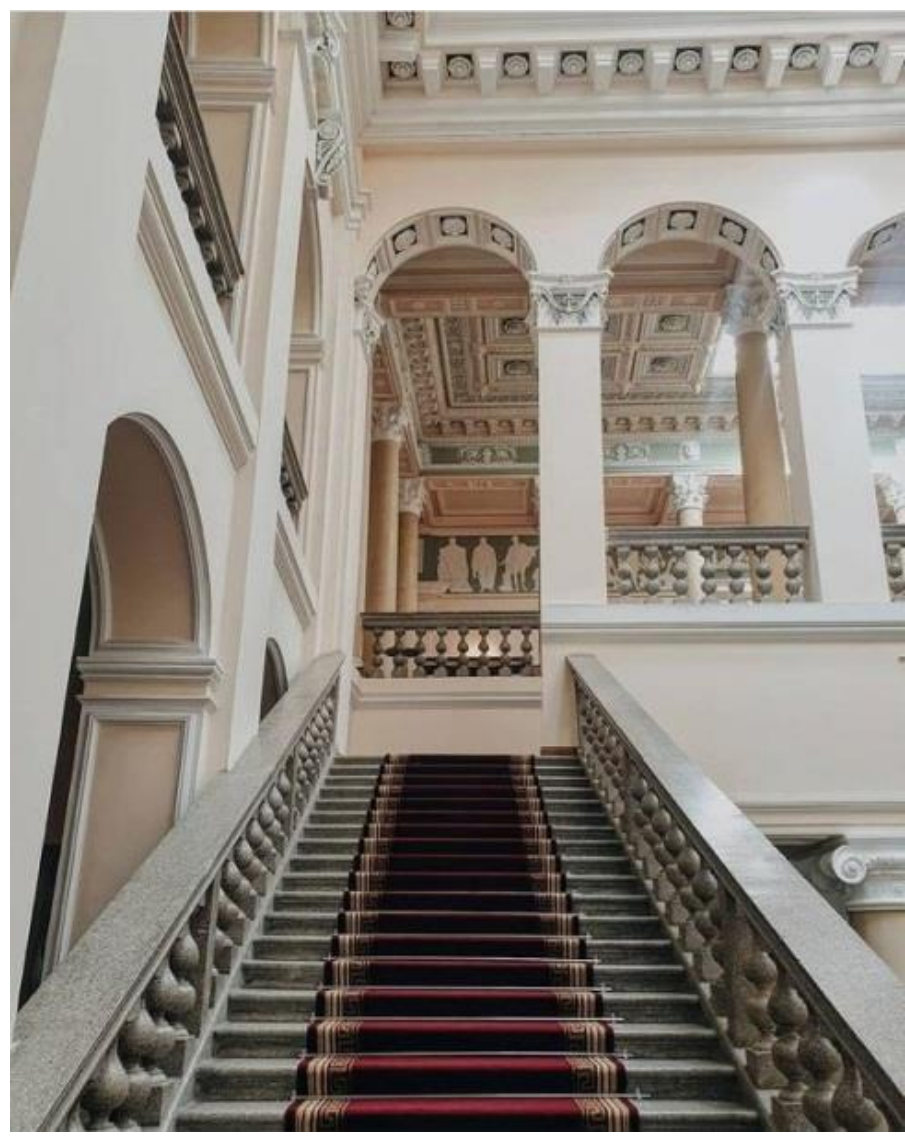

Şekil 13. İsmailiye Sarayı ikinci kata çıkan merdiven (Seyid, 2021).

\subsection{Cephe Özellikleri}

Venedik Gotik tarzında inşa edilmiş sarayın cephesinin mimari özellikleri dikey bir çizgide bir dizi yanal rizalit ile karakterize edilir. Mimar Plosko bu yöntemi tasarımlarında sık 
sık kullanmıştır. Cephenin son derece zarif işlenişi binaya özel bir güzellik ve çekicilik katmıştır. Binanın cephesinde rastgele mimari yöntemler ve formlar gözlenilmemiştir. Cephenin genel mimari bileşimi ile uyumlu olan yatay ve dikey parçaların keskinliği de klasik düzenliliğe örnek olarak gösterilebilir (Fetullayev-Figarov, 2013).

Güzel resimlerle süslenmiş ve sık olarak kullanılmış hacimli birleşik kemerlerden oluşan birinci kat destek kirişleri ile bölümlere ayrılmıştır. Ana girişi, mimari elemanların ve detayların muhteşem bir bileşimini oluşturan sarayın giriş kemeri baş heykelleriyle süslenmiş pilasterlere dayanmaktadır. Cepheye plastik bir görünüm veren taş üzerindeki derin oymalardan giriş bölümünde kullanılmış, kemerli timpan meyve motifleri ile bezenmiştir (Şekil-14,15).
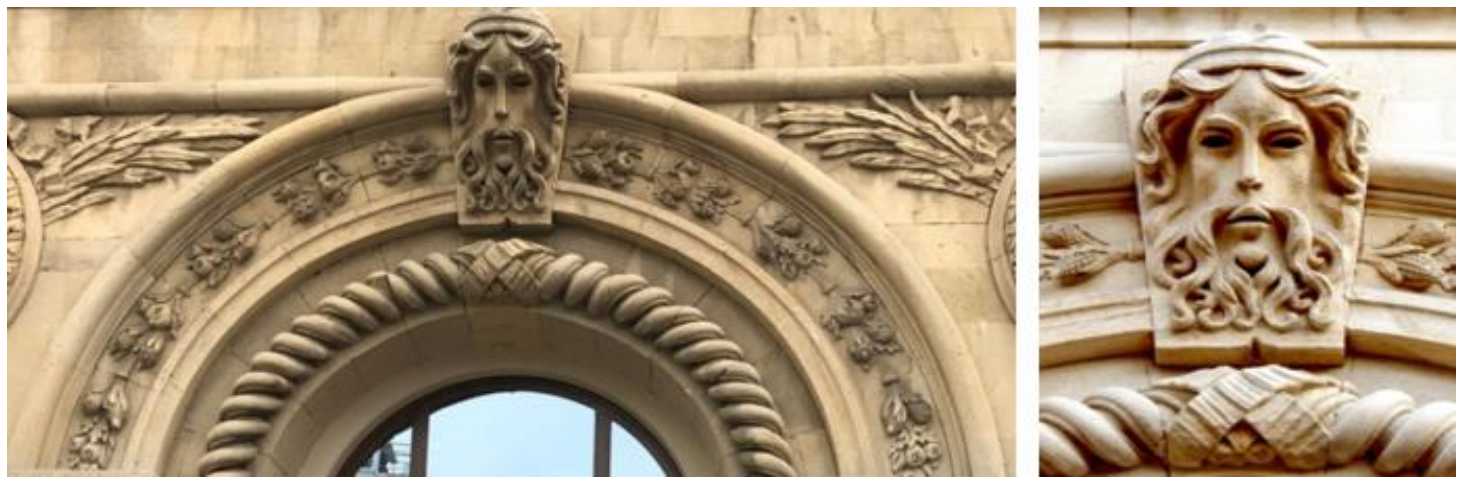

Şekil 14. Binanın giriş kapısında bulunan meyve motifleriyle süslenmiş kemerli timpan (Zeyneb Tahirli, 2021), (URL-1, 2021).

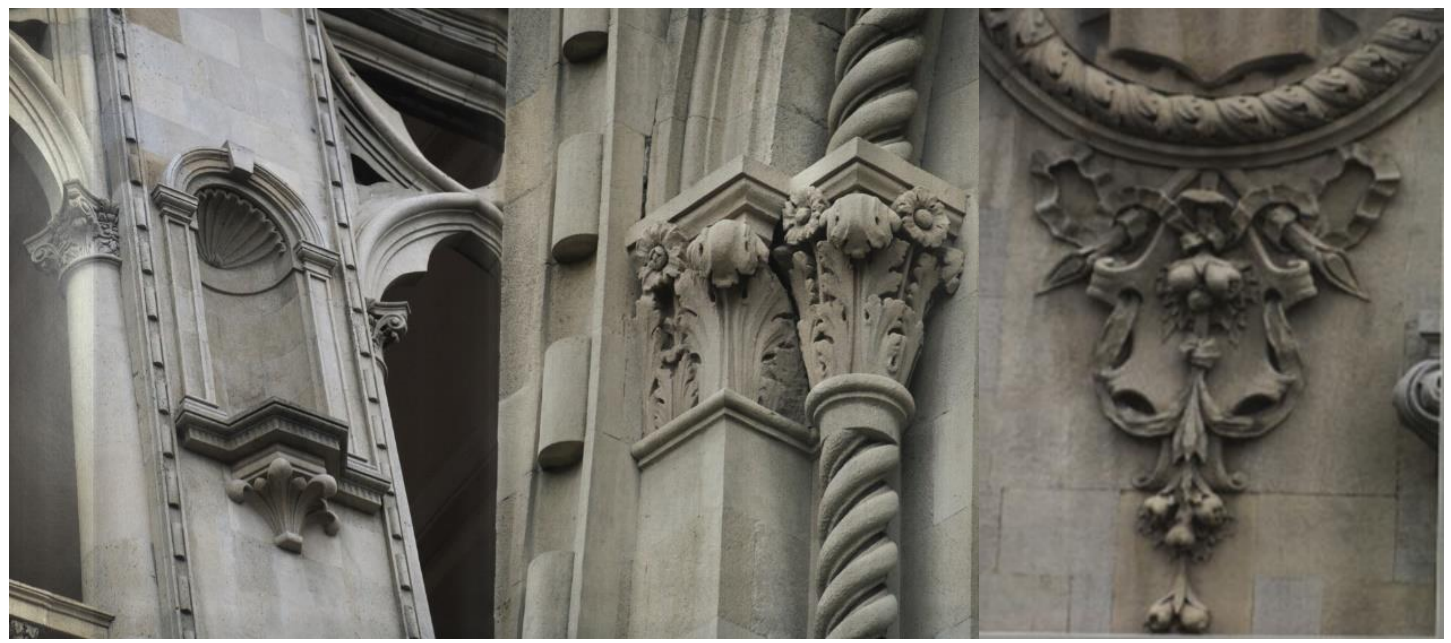

Şekil 15. Cephe Süslemeleri (Tofiqoğlu, 2010).

Ana girişteki dikkat çekici Roma dönemine ait bir figürü andıran baş heykeli ise bütün bir taş bloktan eksiksiz bir şekilde yapılmıştır. Yakındaki kabartma unsurlarıyla bir heykel şeklinde yontulmuş insan başı uyum oluşturmaktadır. Halata benzeyen yarım çember şeklindeki kemerler ise Rönesans dönemi motiflerini anımsatmaktadır (Şekil-14). 
Plosko birleşik kemerler arasında uyum sağlamak ve İsmail'in anısını binada mimari açıdan daha çok vurgulamak için birinci katta kemerler arasında akantus yapraklı, hanedanlık armaları ve taç şekilli dairesel dekoratif motifler kullanmıştır (Şekil-16).

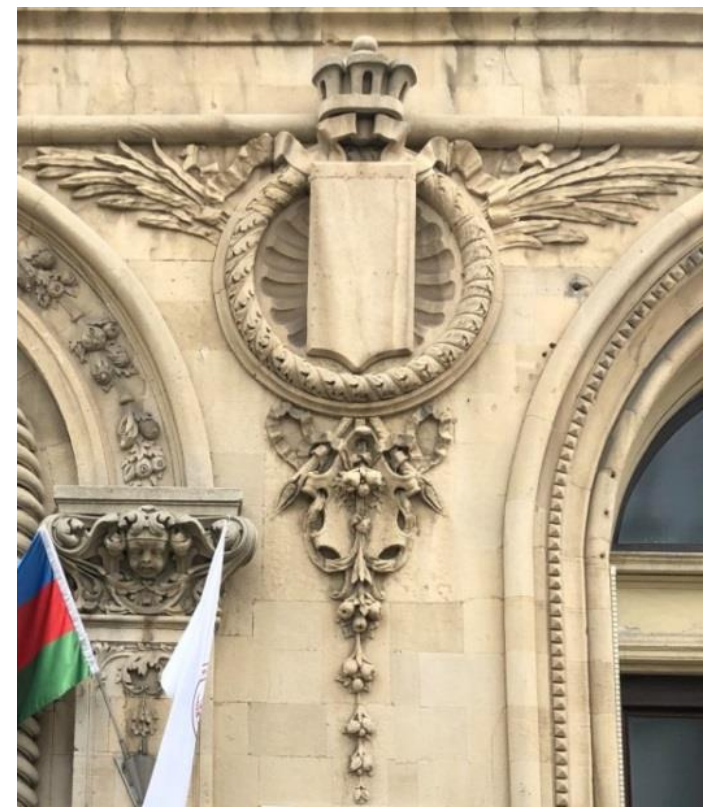

Şekil 16. Giriş kısmında cephede bulunan akantus yapraklı, hanedanlık arması ve taç şekilli dairesel dekoratif motif (Zeyneb Tahirli, 2021).

İkinci kata geçişte geniş bir bölüm şeridi bulunmaktadır. Plosko'nun Ağa Musa Nağıyev'in isteği üzerine tasarlamış olduğu ikinci katın cephesinde "Contarini Delle Figure Sarayı"ndan parçalar görülmektedir. Venedik saraylarında, sivri uçlu birleşik kemerlerin birleşim yöntemi yerini dairesel bir şekle bırakmıştır. Bu birleşim yöntemini Plosko binanın konferans salonunun bulunduğu ikinci katın cephesinde kusursuz bir şekilde kullanmıştır (Şekil17) (Fetullayev-Figarov, 2013). İkinci kat pencerelerinin üzerinde yer alan anahtar deliği motifi ya da yonca motifi olarak bilinen tipik Gotik mimari biçimleri görülmektedir. Çatı bitiş detaylarındaki biçimler yine Venedik’teki sarayı anımsatmaktadır. İkinci katta köşelerde yer alan sivri kemerli büyük pencerelerin kenarlarındaki mozaik bezemeler ise yöre mimarisinden esintiler

taşımaktadır.

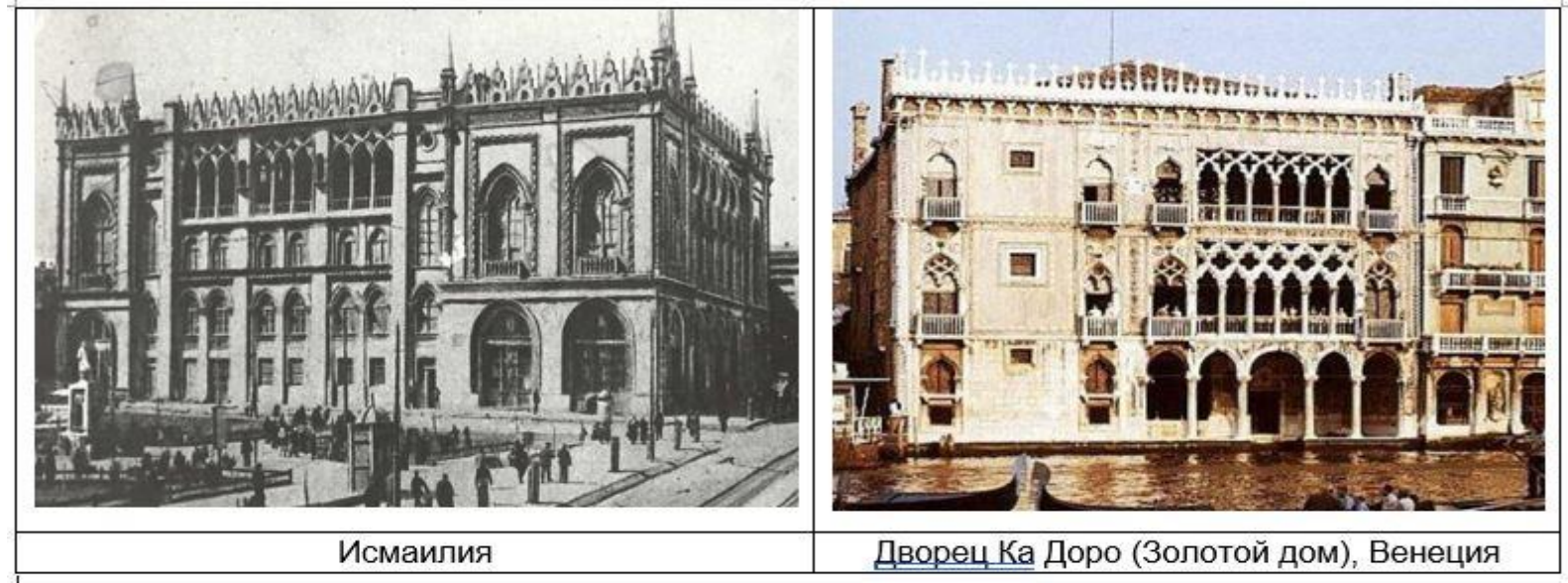

Şekil 17. Contarini Della Figure Sarayı ile İsmailiye Sarayı Benzerliği (URL-12, 2021). 
Zarif korent başlıklara sahip sütunlara dayanan altı kemerli geçişin uyumu cepheye özellik katmıştır.Kemerin ana dayanak elemanı olarak ana kapı (portal) kompozisyonu görevi gören rizalitin kemeri mimari-dekoratif formda yapılmıştır. Kemerin timpanına süs çiçek motifleri işlenmiştir (Şekil-16).

Plosko binanın cephe tasarımında sıklıkla halata benzer detaylara yer vermiş, birbirinden kolon başlıkları ile ayrılan portal kemerler de kullanılmıştır. Ana perspektif kemerleri, bölümler seviyesinde pilasterlere dayanmaktadır.

Rizalit portalı, uzun dikey kolonlara küçük detaylardan oluşan bir akımla bağlanarak, merkezi ekseni ise ana silüet motif görevi gören piramit şekilli alınlıklarla tamamlanmıştır. Projeye göre Plosko rizalitlerin üzerine çeşitli kubbeleri olan yuvarlak kemerler tasarlamıştır. Binanın 1918'de Ermeniler tarafından vurulduğu ve ateşe verildiği sırada yıkıldığına dair kesin bir bilgi yoktur. Ancak bina bu bombardımandan ve yangından ağır hasar görmüştür (Fetullayev-Figarov, 2013).

\section{YAPININ YANGINDAN SONRAKİ DURUMU}

Azerbaycan'ın ünlü şairi Cafer Cabbar 'in (1899- 1934) Ehmed ve Gumru adlı hikayesinde 1918 Mart olayları sonrasında sarayın durumu şu sözlerle ifade edilmiştir: “ Büyük pencereleri kara kümürlere dünmüş, altın duvarlarl matemlere bürünmüş eti dükülmüş baş iskeletine benzeyen muhteşem" (Amanoğlu, 2005).

1918 Mart olayları sırasında binanın yangından sonra avlusuna çıkan yarım dairesel çıkıntıda bulunan merkezi giriş merdiveni tamamen çökmüş, betonarme merdivenler ve kirişler, çatının ve üst güvertenin ağırıklarını taşıyamamıştır. Yangın sırasındaki ateşin sıcaklığından salonların zemin kirişleri bükülmüş ve zeminin düz yüzeyi çatlaklarla dolu dalgalı bir şekil almıştır.

Salonda, fuaye ve merdiven boşluklarında bulunan dekoratif süslemeler yangının sıcaklığından, duvar taşlarının tutuşmasından ayrılmış ve bazı yerlerde parçalanmışlardır. Ateşin sıcaklığına maruz kalan duvar taşlarının kalitesi o kadar düşmüştür ki, artık yapı malzemesi olarak

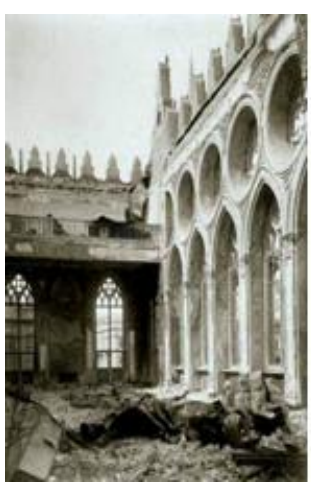

kullanılmaz

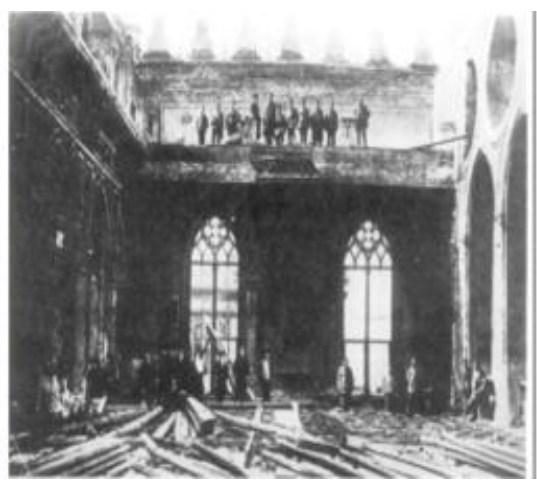

hale

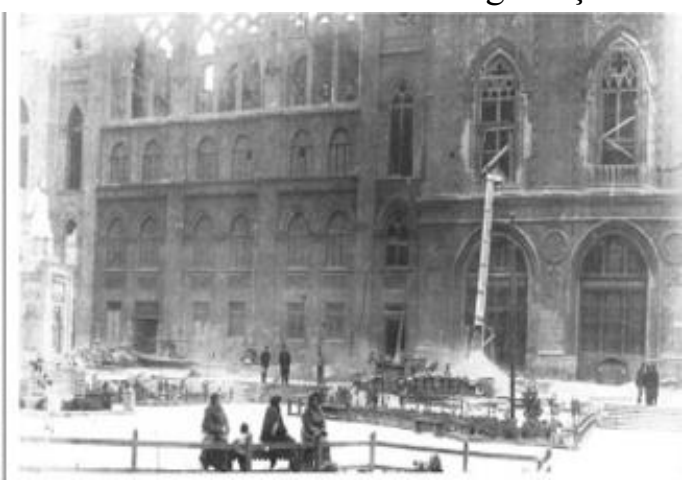

Şekil 18. 1918 Mart soykırımından sonra İsmailiye Sarayı ve 1922 yılındaki restorasyondan görünümler (URL-12, 2021).

Birkaç sene sonra Azerbaycan'da iktidarı ele geçiren SSCB binayı yıkma kararı almış olsa da, halkın itirazı sebebiyle binanın restore edilmesine karar verilmiştir (URL-1, 2021). 
2 Kasım 1918'de Azerbaycan Demokratik Cumhuriyeti hükümeti, binanın hasarını değerlendirmek için mühendis A.I.Sternberg'in önderliğinde olağanüstü bir komisyon oluşturduktan sonra komisyonun sonuçlarına göre, binanın hacmi 3.000 kulaç küp olarak hesaplanmıştır. 1907-1908'de binanın inşası için yaklaşık 330.000 ruble harcanmıştır. Binanın restorasyon işleri önce Ermeni mimar Vartan Sarkisov'a, sonradan ise betonarme yapılar konusunda uzman Alexander Dubov'a havale edilmiştir (URL-1, 2021). Dubov 1922-1923 yıllarında binanın restorasyonunu yapmıştır (URL-14) (URL-12, 2021).

\section{YAPININ GÜNCEL DURUMUNUN İNCELENMESI}

Restorasyon sırasında sarayın genel planında değişiklik yapılmasa da cephe tasarımında değişiklikler olmuştur. Şöyle ki, Sovyetler, Kızıl Ordu'nun bayrağı olarak kabul edilen beş köşeli yıldızı, yazılı kaynaklardan bilindiği üzere bir zamanlar üzerinde Kur'an-1 Kerim'den ayetler ve hadislerin yer aldığı madalyonlara eklemiştir (Şekil-19) (URL-10, 2021).

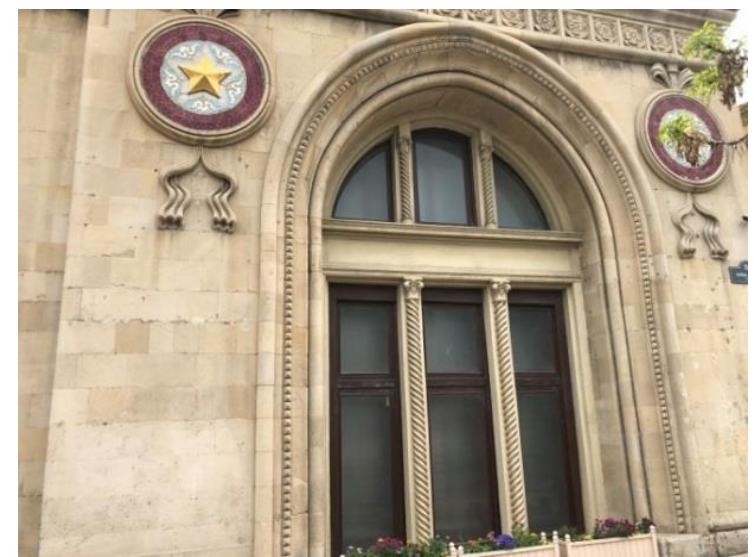

Şekil 19. Restorasyon sonrasında üzerine SSCB kızıl yıldızı eklenmiş madalyonlar (Zeyneb Tahirli, 2021).

Restorasyon sırasında yapılmış bir başka değişiklik de binanın ilk yapımında mimar Plosko, projesine göre kubbeler tasarlamış olsa da restorasyon sonrası kubbeler yerine binanın esas silüet motifleri rolündeki piramit şekilli frontonlara benzer tasarımın uygulanmış olmasıdır (Şekil-20). Plosko'nun projesine göre ve İsmailiye Sarayı'nın mimari kompozisyouna uygun olarak, rizalitlerin üzerine farklı örtülü kubbelere sahip yuvarlak kemerler yerleştirilmiştir. 1918 'de binanın bu kemerlerinin yıkıldığına dair kesin bir bilgi elde edilememiştir. Ancak bina belirtildiği gibi yangın sırasında çok ciddi hasar görmüştür (Şekil-18,21) (Fetullayev-Figarov, 2013).

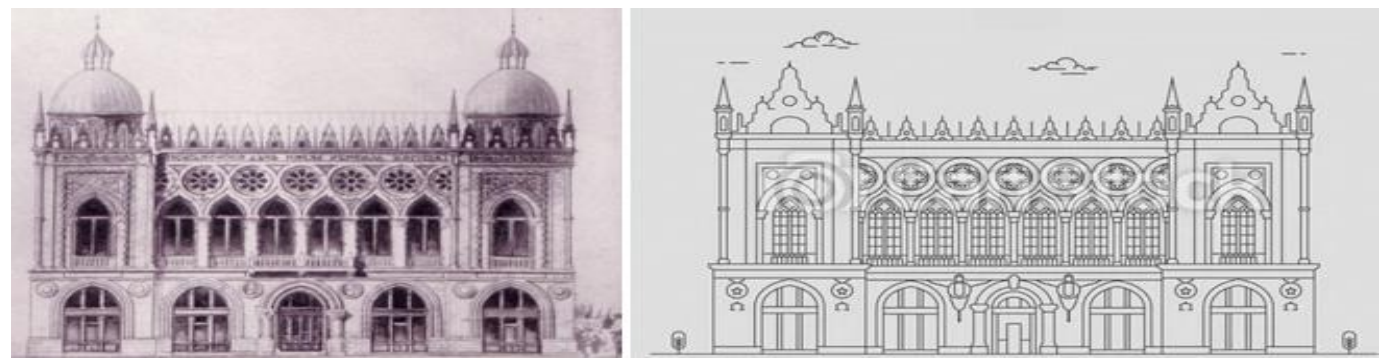

Şekil 20. Plosko’nun projesine göre İsmailiye Sarayı cephesi (URL-1, 2021) ve günümüzdeki durumu (URL-11, 2021). 


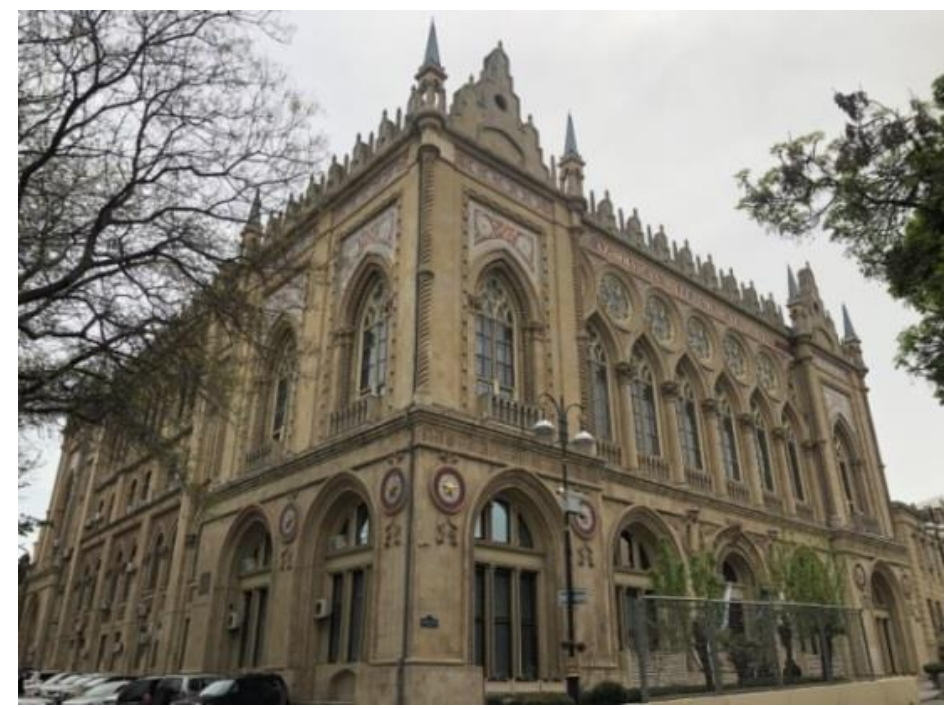

Şekil 21. İsmailiye Sarayı'nın restorasyon sonrasındaki durumu (Zeyneb Tahirli, 2021).

Musa Nağıyev tarafından oğlu İsmail'in anısını yaşatmak için yaptırılan, Bakü’nün önemli mimari yapılarından olan bu sarayın bir zamanlar ön cephesinde altın harflerle yazılı olan "İsmailiyye" yazısı da restorasyon sonrası yapılmamış, sonradan onun yerine "Azerbaycan SSCB Bilimler Akademisi" yazısı eklenmiştir. 2020 yılına kadar herhangi bir onarım veya değişiklik görmemiş olan binada 2020 y1lında hasarların giderilmesine yönelik restorasyon yapılmıştır.

\section{BULGULAR VE SONUÇ}

Yapılan çalışmada ilk başta Müslüman Hayır Cemiyeti olarak kullanılan İsmailiye Sarayı'nın geçirmiş olduğu restorasyon süreci sonucunda orijinal halini korumadığı sonucuna gelinmiştir. İsmailiye Sarayı cephesinde restorasyon sonrasında aşağıda sıralanan değişiklikler yapılmıştır:

a.Cephede bulunan bir zamanlar üzerinde Kur'an-1 Kerim'den ayetler ve hadislerin yer aldığı madalyonların üzerine restorasyon sonrası SSCB beş köşeli kızıl yıldızı eklenmiştir.

b. Mimar Plosko'nun projesine göre çizilmiş olan kubbelerin restorasyon sonrasında yerinde yapının esas silüet motifleri rolündeki piramit şekilli frontonlara benzer tasarımlar yapılmıştır.

c.İlk başta Müslüman Hayır Cemiyeti (kurumu) için yapılmış olsa da restorasyon sonrasında farklı işlevler için kullanılmış, en son Azerbaycan Ulusal Bilimler Akademisi olarak kullanılmaya başlanmıştır.

d. Sarayın adı değiştirilmiş ve cephesinde bulunan "İsmailiyye" yazısı kaldırılmıştır.

Her zaman toplumları ele almayı, özünü kimliğini unutturmayı, çalıştırmayı hedefleyen Sovyetler Sosyalist Cumhuriyetler Birliği İsmailiye Sarayı cephesinde yaptığı değişikliklerle hedefinden vazgeçmemiştir.

İnsanları dinden uzaklaştırmaya çalışan SSCB var olduğu müddetçe SSCB'ye bağlı hiçbir ülkede insanların inançlarını rahat bir şekilde yaşayabilmelerine izin vermemiştir. Bundan 
dolayıdır ki İsmailiye Sarayı cephesinde de aynı fikri uygulamış, İslam dininin mimarideki simgesi olarak kabul edilen kubbeleri yaptırmamıştır.

1991 yılında SSCB'nin dağılması ve Azerbaycan'ın bağımsızlığını kazanmasına rağmen, günümüzde de Sovyetlerin kalıntılarını görebilmek mümkündür. İsmailiye Sarayı gibi birçok binaya beşköşeli yıldızını eklemiş olan Sovyetler, bazı insanların düşüncesinde ülkeye faydalı işler görmüş; okullar, tiyatrolar, saraylar yaptırmış bir iktidar olarak kalmıştır. Oysa ki bu yapıları Sovyetler değil, zamanında ekonomik durumu iyi olan Ağa Musa Nağıyev gibi ülkesine faydalı, hayırsever insanlar yaptırmıştır.

Sarayda Ermeniler tarafından yapılan saldırılar sebebiyle binanın bütün arşivi yanmış ve yok edilmiştir. Bundan dolayıdır ki günümüze İsmailiye Sarayı ve onun gibi birçok yapılarla ilgili belgeler çok az ulaşmıştır.

Yapılan çalışmada yapının yangından önceki hali ve restorasyon sonrası hali incelenmiş ve restorasyon sonrası binanın orijinal halini koruyamadığı sonucuna varılmıştır.

Muhteşem İsmailiye Sarayı 100 yıldan daha eskidir, ancak her zaman mimarın becerisine ve malzemede gerçek bir mimari senfoni oluşturan duvar ustalarının sanatına hayranlık uyandırır. "İsmailiyye" tam taştan örülme bir mimari şiirdir. Güzelliği ve anıtsal yüzüyle şehrin ve Azerbaycan'ın çevresindeki binalardan ayırt edilir. Ulusal mirasın eşsiz bir mimari anıtı olarak kabul edilir.

Azerbaycan genelinde Azerbaycan mimarisinin önemli örneklerinin restore edilerek özgün hallerine geri döndürülmeleri, Azerbaycan halkının kültürel özünü benimseyerek koruyabilmesi için bilinçlendirilmeleri gerekmektedir. İsmailiye Sarayı başta olmak üzere bu tür önemli yapıların rölövelerinin çıkarılarak restorasyon çalışmalarının yazılı kaynaklara tanitılması gerekmektedir.

\section{KAYNAKÇA}

Aliyev, İ. (2007). "Memarlıq". Azarbaycan Millı Ensiklopediyası, Bakü. s. 750-760.

Amanoğlu, E. (2005). "Bakü'de Ermenilerin Yaptıkları Soykırım (Mart 1918) ve Edebiyatta Yansımaları". Karadeniz Araştırmaları(5), s.99-107.

Boni, F. D. (2018). "Baku and Architecture: From Soviet Building to Archistars". Geopolitical, Social Security and Freedom Journal, 1(2), s.76-83.

Budak, A. (2018). "Müsavat Partisinin 1911 - 1922 Y1lları Arasındaki Faaliyetleri”. Firat Üniversitesi Sosyal Bilimler Dergisi, 28(2), s.333-343.

Durmaz, Ş. (2010). “20.Yüzyılın Başında Azerbaycan'da Sosyal Yardımlaşma ve Dayanışma Amaçlı Vakıf ve Dernekler". Türkiye Cumhuriyeti Başbakanlık Sosyal Yardımlaşma ve Dayanışma Genel Müdürlüğü Yardım ve Dayanışma Hakemli Araştırma Dergisi, 1(1), s.61-69.

Dursun, D. (1991). "Bakü Azerbaycan Cumhuriyeti'nin Başşehri”. TDV İslam Ansiklopedisi, 4, s.550-551.

Erdoğan, F. (1998). Türk Ellerinde Hatıralarım (buraxılış 1.Bask1). Ankara: T.C.Kültür Bakanlığı Yayınları . 
Ferhadoğlu, K. (2006). Bakı. İçərişəhər. Bakü.

Fetullayev-Figarov, Ş. (2013). Memar İ.K.Ploşko-"İsmailiyyə"nin Müallifi. Bakü: Ami.

Giyasi , C. (2015, 04 03). "Ortaçağ Azerbaycan Mimarisi”. İrs Sanat Dergisi,, s.50-57, http://www.azbtt.com/pdf/1469527298-7h6dgoclui-12.pdf

Quretski, V. (2012). Bakı: Bakıda Polyak məkanları. Bakü: Polşa Respublikasının Bakıdakı Səfirliyi.

Resulzade, M. E. (1990). Azerbaycan Cumhuriyeti Keyfiyet-i Teşekkülü ve Şimdiki Vaziyeti. İstanbul: İrfan Yayınevi.

Seyid, N. (2021). Ísmailiyyə Sarayı İkinci Mərtəbə. Bakü.

Sipahi, E. B. (2018). “Bakü’nün Başkent Olma Süreci Üzerine Bir Analiz.” Müsəlman Şərqində ilk Parlamentli Respublika, Bakü. s. 982-989.

Fetullayev-Figarov, Ş. (2013). "İçeri Şeherin Etrafi Boyunca Dairevi Magistral.” Bakının Memarlıq Ensiklopediyası. Bakı:Azerbaycan Respublikasının Memarlar İttifaq1.

Tofiqoğlu, A. E. (2010). Bakı Memarlıq Abidələrində Fasad Heykaltəraşlıq Nümunaləri: XIX Asrin Sonu-XX Asrin Әvvallari. Bakü.

URL-1. (2021, $03 \quad$ 02). Ismailiye Sarayl. $\mathrm{Bu}$ Wikipedia: https://az.wikipedia.org/wiki/\%C4\%B0smailiyy\%C9\%99_Saray\%C4\%B1

URL-2. (2021, 04 03). Azıx mağarası. Bu Azərbaycan Respublikası Xocavənd Rayon İcra Hakimiyyəti: http://www.xocavend-ih.gov.az/page/141.html

URL-3. (tarixsiz). $7 \quad 7, \quad 2021$ tarixində bu Wikipedia: https://tr.wikipedia.org/wiki/Azerbaycan_mimarisi

URL-4. (2021, 06 22). Darband qalast. Bu Tarix.info: https://tarix.0101.az/abideler/80d601rb601nd-qalas305.html

URL-5. (2021, 06 22). Yuxarl Karvansaray. $\mathrm{Bu}$ Wikipedia: https://az.wikipedia.org/wiki/Yuxar\%C4\%B1_Karvansara_(\%C5\%9E\%C9\%99ki)\#/me dia/Fayl:Yukhari_kervansarai_2.JPG

URL-6. (2021, 06 22). Bakl. Hökümat evi. Tarix va miras. $\mathrm{Bu} \mathrm{Az}$ Loqos: https://azlogos.eu/baki-hokum\%C9\%99t-evi-tarix-v\%C9\%99-miras/

URL-7. (2021, 06 19). Nizami kinoteatrı. Bu Nostalgiya: https://nostalgiya.az/azerbaycan/754nizami-kinoteatri-baki-1961-ci-il.html mənbədən tap1lib

URL-8. (2021, 04 11). Haydar Eliyev Kültür Merkezi. Bu Arkitektuel: https://www.arkitektuel.com/haydar-aliyev-kultur-

merkezi/zha_heydar_aliyev_centre_baku_huftoncrow_001 mənbədən tapilib

URL-9. (2021, 06 21). Baku Flame Tower. Bu KOPRULULER INC.: https://koprululer.com.tr/projeler/baku-flame-tower/ 
Azerbaycan Tarihinde Önemli Yeri Olan İsmailiye Sarayı'nın Eski ve Güncel Durumunun Incelenmesi

URL-10. (2021). Xəsis milyonçu Musa Nağıyev vo Bakının "qızıl binası". Bu https://www.kultura.az/az/article/2654/

URL-11. (2021, 06 28). Ismailiyya building. Bu Can stock photo: https://www.canstockphoto.com/ismailiyya-building-in-baku-azerbaijan-79076020.html

URL-12. (2021, 06 28). Жемчужина бакинской архитектуры «Исмаилия». Ви Окна в Баку: https://www.window2baku.com/ismailiya.htm

URL-13. (2012). "Bakl vaxtı - İsmailiyya binası" filmi - Íctimai TV. Haziran 28, 2021 tarixində bu https://www.youtube.com/watch?v=A8nz-jWkfmA mənbədən tap1lib

URL-14. (tarixsiz). Temmuz 7, 2021 tarixində bu https://www.baku.ru/encshow.php?id=141832\&cmm_id=276\&slang=ru

Valiyev, A. (2013). "Baku". Cities, 31, 625-640.

Yagublu, N. (2015). Mehmet Emin Resulzade Ansiklopedisi. Ankara: "Azerbaycan Kültür Derneği”" Yayınları. 